\title{
TEMATSKA MOZAIČNOST I ŽANROVSKE MODIFIKACIJE U SARAJEVSKOM MARLBORU MILJENKA JERGOVIĆA
}

\author{
Polina Korolkova \\ Rusko državno humanističko sveučilište
}

U zbirci priča Miljenka Jergovića Sarajevski Marlboro nalaze se posve različiti tekstovi koji bi sami po sebi mogli pripadati različitim žanrovima. To su skice i eseji, monolozi i dijalozi, u njima možemo vidjeti čak i bajku. Takvo šarenilo koje je u ovom slučaju ponajprije rezultat autorskih ciljeva i zadataka (nacrtati živu sliku grada, prikazati ljude iz različitih slojeva društva, različitih nacionalnosti i uzrasta, njihov život u opkoljenom Sarajevu), postaje prava vrlina ovog teksta.

Iako knjiga opisuje ratno razdoblje, u njoj nećemo naći opise bombardiranja grada, ljudskih stradanja, filozofije oko smisla rata i nasilja, života i smrti i sl. U članku će biti predloženi odgovori na pitanja: kako i zašto autor krši očekivanja čitatelja u temi i žanru, čemu služi princip žanrovske hibridizacije i tematsko šarenilo, te kako su oni povezani, zašto se Sarajevski Marlboro može čitati isključivo kao tekst u kojem svi dijelovi čine jednu cjelinu.

Ključne riječi: hrvatska književnost, Miljenko Jergović, Sarajevski Marlboro, skica, esej.

\section{UVOD}

Zbirka priča Miljenka Jergovića Sarajevski Marlboro smatra se jednim od najuspješnijih i najpoznatijih književnih tekstova poslijeratnog doba. Prvi put objavljena 1994. godine, ova zbirka priča do danas ostaje klasičan tekst o ratu u Bosni i Hercegovini. U članku će se razmatrati nekoliko pitanja, a među njima se izdvajaju sljedeća: kako je Jergović, uz pomoć principa hibridizacije žanrova, uspio ostvariti atmosferu opkoljenog grada koju čitatelj osjeća gotovo na tjelesnoj razini, kako su te žanrovske modifikacije povezane sa tematskim šarenilom i zašto je Sarajevski Marlboro toliko popularan kod čitatelja skoro na cijelom području bivše Jugoslavije.

\section{Tematsko određenje zbirke}

Prije nego što se krene analizirati Sarajevski Marlboro s gledišta žanra, treba reći nešto o tematici, kompoziciji i junacima u knjizi. Tematsko određenje zbirke upućuje na tekst o bolesnom raspadu hibridnog povijesno-kulturnog prostora, o nestanku Sarajeva kao unikatnog mikrosvijeta - procesu koji je na isti način strašan 
za junake različitih nacionalnosti, vjeroispovjesti i sudbina. Međutim, dok izgrađuje naraciju o opkoljenom gradu i njegovim stanovnicima, Jergović istodobno izaziva tradicije ratne književnosti jer, pričajući o nekim od najstrašnijih epizoda $u$ tom krvavom ratu, pisac u većini slučajeva ostavlja po strani kadriranja ratnih slika, a stradanja i smrt najčešće opisuje kao činjenicu koja nije presudna za konkretnu priču (pripovijetke Dijagnoza, Fotografija i dr.): "Salihu F. četnici su pred njegovim očima motornom pilom izrezali ženu i dvije kćeri. Njega su strpali na Manjaču da tamo crkne, ali nije crknuo, nego je dočekao neku razmjenu. Prebacili su ga $\mathrm{u}$ Gradišku, pa u Karlovac, pa u Češku. Tamo je završio u nekom izbjegličkom logoru, među nepoznatim mahom bosanskim svijetom. Nepismen i spor na mislima, postao je idealnim predmetom opće zajebancije" (Jergović, 2004, 86). Početak priče Dijagnoza zvuči tim strašnije, što, na prvi pogled, ubojstvo obitelji ne ostavlja u duši junaka nikakav duboki trag, cijela priča je posvećena njegovoj borbi s provokatorima u izbjegličkom logoru, skitanjima po Češkoj i boravku u ludoj kući gdje na kraju ispada pametniji i mudriji od svih liječnika. ${ }^{1}$

Dakle, iako knjiga opisuje ratno razdoblje, u njoj se ne susreću detaljni opisi bombardiranja grada, ljudskih stradanja, filozofiranja oko smisla rata i nasilja, života i smrti i sl. Naprotiv, u središtu pažnje je svakodnevnica i to takva u kojoj ima mjesta za obiteljske drame i prevare, ljubav i ljubomoru, prijateljske pijanke i čuveni sarajevski humor, ponekad komične, ponekad romantične, ponekad tužne situacije, a junaci su sasvim obični ljudi u čijim karakterima i postupcima nema ništa junačko ili posebno i na koje rat u biti gotovo pa ne utječe. To doista jesu priče o ratnom razdoblju, ali je većinu njih teško nazvati ratnim pripovijetkama i to upravo stoga, jer se bave ponajprije ljudskom suštinom koja ne ovisi o okolnostima i o kontekstu. Uslijed toga, opkoljeni grad koji se ne može napustiti, postaje model cijeloga svijeta. Kako bi se taj svijet opisao u svoj svojoj cjelovitosti i višeslojnosti, Jergović smješta pod jedan naslov tekstove posve različite po svom karakteru i dinamici, tematici i stilu. Upravo takvim, mozaičnim pripovijedanjem, pisac daje pravu sliku ljudskog života u umjetnički stvorenom hermetičnom svijetu jednoga doista hibridnog grada.

Zato je sasvim logično da se za ostvarivanje Jergovićeve ideje kao najbolji prozni žanr nameće upravo pripovijetka ${ }^{2}$ - kraća prozna vrsta, čija "srednja dužina" "može uključivati kako postupke karakteristične za novelu u nešto proširenom obliku, tako i postupke romana „sažete“ na manji obim“ (Solar, 2007, 298). Zbirka pripovijedaka može pružiti čitatelju šareniji i višestraniji životni mozaik, nego novela ili roman. U tom smislu, Miljenka Jergovića bismo bez ikakve sumnje mogli nazvati sjajnim učenikom Antona Pavloviča Čehova (o čemu otvoreno govori i sâm autor Sarajevskog Marlbora ${ }^{3}$ ) - jednog od malobrojnih ruskih pisaca koji iza sebe nije ostavio niti jedan roman, ali se niz njegovih vrhunskih pripovijedaka nerijetko doživljava kao sažeti romani.

S druge strane, Jergovićeve priče nisu sasvim samostalne. Sâm pisac priznaje da Sarajevski Marlboro predstavlja jednu cjelinu koja se treba čitati kao roman - od prve do poslednje riječi, ne mijenjajući redoslijed pripovijedaka pri njihovu iščitavanju. Nije slučajno niti to da se i u kompoziciji koju čine 3 dijela može pročitati romanska zamisao: ulogu predgovora (prologa) figurira prvi dio (Nezaobilazan detalj u biografiji) koji čini samo jedna pripovijetka Izlet, ulogu epiloga figurira treći dio Who will be the witness, koji čini također samo jedna skica, 
kratki tekst naslovljen Biblioteka. Osim toga, skoro svaka pojedinačna priča, izvučena iz konteksta cijele zbirke, gubi veći dio svojega smisla, te se sama po sebi vrlo teško može doživjeti kao tekst koji nosi samostalnu poruku.

Upravo zbog svega navedenog, čitateljeva očekivanja ostaju iznevjerena. Uzimajući u ruke Sarajevski Marlboro, čitatelj je spreman za užase ratnih događaja, ne i za priče u kojima se rat samo naslućuje, ali se zato dobiva detaljna informacija o, primjerice, održavanju kaktusa i dječjem izletu u Jajce (ovim dvjema pripovjetkma - Izlet i Kaktus - otpočinje knjiga), ili priče u kojima su ratne realnosti samo povod za razgovor o nekim, na prvi pogled, sasvim drugim stvarima (već spomenuta Dijagnoza, Bosanski lonac, Komunist i dr.). Međutim, i tamo gdje su prisutni opisi ratnih realnosti - bombardiranja, ranjavanja, bola i smrti - akcentira se, kao što je već rečeno, svakodnevna strana života, pojavljuju se čak i različite nijanse komičnog - od meke ironije, do satire i groteske. Jedini izuzetak čini pripovijetka Pismo u kojoj su razmišljanja o ratu, raspadu Jugoslavije i odnosima Srba, Hrvata i Bošnjaka povjerena strancu - studentu, koji je napustio Sarajevo na početku rata i sada traži svog prijatelja, ne znajući za njegovu smrt.

Još jedno Jergovićevo polje kršenja čitateljskih očekivanja svakako je i kompozicija priča - ponajprije odsutnost kulminacije i, na prvi pogled, nelogičnosti u postupanjima glavnih junaka čije sudbine otvaraju brojna pitanja na koja se odgovori na neki način pojavljuju tek kasnije, u sasvim drugim pripovijetkama. U tom smislu i naziv osnovnog dijela (Rekonstrukcija događaja) jedna je velika piščeva "prevara", odnosno igra, ironija, zagonetka, jer je Jergovićevo pripovijedanje posve udaljeno od dokumentarne kronike na koju najmanje liči. Zanimljivi su i pasaži u kojima pisac stupa u igru s čitateljem, te mu se čak na neki način $\mathrm{i}$ ispričava zbog odsutne radnje $\mathrm{i}$ poante (Putovanje): "Priča o Jurišićima zapravo je sretna priča. Svi su živi i nije im se dogodilo ništa neobično, čak ništa što bi se moglo iskoristiti kao poanta" (Jergović, 2004, 101). ${ }^{4}$ Takva književna rješenja trebaju stvoriti kod čitatelja osjećaj napetosti, kaosa i besmisla rata, zbunjenosti u ljudskim dušama. Paradoksalnost $i$ apsurd ratnih realnosti diktira paradoksalnost $i$ šarolikost tekstova, te orijentiranost na traumiranje čitateljskih očekivanja.

Sustav junaka Sarajevskog Marlobora također je, u najmanju ruku, šarolik. To su ljudi različitog uzrasta, nacionalnosti (uključujući i strance) i socijalnog statusa, čiji govor Jergović često podražava i oponaša govorom svojih junaka. U zbirci se tako mogu pronaći pripovijetke pisane i u prvom, i u drugom i u trećem licu. Otprilike, trećinu tekstova čine priče napisane u prvom licu jednine, u kojima su pripovjedači djeca i stariji ljudi, muškarci i žene, obrazovani i neobrazovani. Zanimljivo je i to da se njihova obilježja prepoznaju po govoru. Među njima nalaze se i osobe koje čitatelj simpatizira, ali i pripovjedači koji će najvjerojatnije izazvati negativne emocije (Saksofonist). Ima i junaka prema kojima se odnos citatelja $\mathrm{s}$ vremenom mijenja zbog jednog jedinog detalja ili neke činjenice, koju čitatelj doznaje tek na kraju priče (Hanumica, Vojvoda).

$\mathrm{Na}$ taj način Jergović crta generalizirani portret Sarajlije, ne akcentirajući nacionalne aspekte rata i ne zauzimajući ni prosrpski, ni probošnjački, ni prohrvatski stav, te na taj način prenosi i osnovni princip svojih junaka koji nemaju smisla za 
politiku, nego sanjaju samo mir i siguran život (kako je to, primjerice, prikazano u priči Gong). Jergovićev je junak čovjek koji je izgubio tlo - nevažno iz kojih razloga - bilo onih "ozbiljnih" (obitelj koja je napustila grad, ili pogibija bliske osobe), bilo onih koji se čine "neozbiljnima" (kao u priči Deklinacija gdje svećenik brani djetetu iz muslimanske bošnjačke obitelji ići u crkvu, a zbog govora ga zadirkuje djevojka iz razreda u koju je zaljubljen).

Međutim, u Sarajevskom Marlboru, govoreći u širem smislu, nije portretirano samo Sarajevo i njegovo stanovništvo, nego i Bosna i Hercegovina, te sudbina i budućnost ove iznimno posebne zemlje s brojnim promjenama koje su se dogodile na njezinom prostoru, u ljudskim životima i dušama. Dovršetkom čitanja Sarajevskog Marlbora čitatelj ipak ne dobiva konkretne odgovore, nego, upravo suprotno, materijal za razmišljanja u obliku simbola, slika, detalja (primjerice, simbol jabuke u pripovijetci Krađa i dr.). Po istom principu ulogu simbola dobiva i glineni lonac (Bosanski lonac), te se u njemu čita hibridna priroda Bosne i Hercegovine. Sudbina te posude postaje metafora za sudbinu cijele zemlje: momak Bošnjak i njegova djevojka Hrvatica iz Zagreba pokušavaju skuhati specijalitet koji se zove "bosanski lonac", ali junaci prekidaju, momak odlazi iz grada, i lonac ostaje zauvijek prazan i nepotreban: "Lonac nikada nije upotrijebljen. Ostao je u kuhinji kao prazna saksija, dok se ne razbije ili dok ga se ne dokopa neki drugi Bosanac" (Jergović, 2004, 35).

Svaka pripovijetka, dakle, sadrži više neizgovorenog nego izgovorenog, nosi atmosferu, ali ne i detaljne opise - ljudskih karaktera i konkretnih događaja. Zato su u ovim pričama iznimno važni detalji i simboli, koji govore više od riječi. Upravo oni kod Jergovića postaju glavni nositelji smisla, bez njih često nije moguće shvatiti autorsku intenciju. Vjerojatno svaki od čitatelja nalazi u knjizi detalj ili simbol koji je za njega najupečatljiviji i najslikovitiji. Određeni detalj koji postaje dominanta, postoji skoro u svakoj priči (kaktus, jabuka, prsten, grob, slika itd.), dok razvijen sustav motiva i tema Bosne i Hercegovine spajaju tekstove posve različitih karaktera, tematike i žanrova.

U skladu s tematskim šarenilom, u zbirci priča Miljenka Jergovića susreću se posve različiti tekstovi koji bi sami po sebi mogli pripadati različitim žanrovima, premda se njihov spoj u Sarajevskom Marlboru smatra zbirkom priča. To su i skice i eseji i monolozi i pismo, pripovijetka u pripovijeci i pismo u pripovijeci (Pismo), monolog (priče Komunist, Grob), ili kazivanje, odnosno skaz, kako bi ga odredili ruski teoretičari književnosti. ${ }^{5}$ Primjerice, junak Jergovićeve priče Komunist govori o svom poznaniku, predsjedniku općine, njegova riječ, kao i riječ grobara iz one druge priče stilizirana je kao usmeni govor $u$ kojem su sačuvane njegove fonetske $i$ gramatičke osobine ("čoek" umjesto "čovjek", "šeset" umjesto "šezdeset", "poso" umjesto "posao", dijalektne, neknjiževne riječi i sl.). Kao primjer skice mogla bi se navesti priča Biblioteka - poslednja priča u zbirci, koja predstavlja filozofski esej posvećen zapaljenoj biblioteci i izgorjelim knjigama u doba rata. Publicističnost ove priče akcentirana je i izborom drugoga lica jednine. 


\section{ZAKLJUČAK}

Sve nabrojano potvrđuje da autor krši očekivanja čitatelja u temi i žanru, a navedeno postiže uporabom principa žanrovske hibridizacije i tematskoga šarenila (mozaičnosti) - dviju odlika toliko čvrsto povezanih da postaju stilskom dominantom teksta. Zato se Sarajevski Marlboro može čitati isključivo kao tekst u kojem svi dijelovi čine jednu cjelinu. Takvo šarenilo, koje je u ovom slučaju ponajprije rezultat autorskih ciljeva i zadataka (nacrtati živu sliku grada, prikazati ljude iz različitih slojeva društva, različitih nacionalnosti i uzrasta, njihov život u opkoljenom Sarajevu i, na kraju krajeva, nacrtati sliku cijele Bosne i Hercegovine kao izgubljenog svijeta i postaviti probleme općeljudskog karaktera, poput milosrđa i okrutnosti, ljubavi i smrti, snage i slabosti i sl.), postaje prava vrlina ovog teksta koji ni na trenutak ne pušta čitateljsku pažnju, jer nijedna priča ni u kojem aspektu ne sliči na prethodnu.

\section{Reference}

Jergović, M. (2004). Sarajevski Marlboro. Zagreb: Biblioteka Jutarnjeg lista.

Solar, M. (2007). Književni leksikon. Zagreb: Matica Hrvatska.

Королькова, П. (2014). Сборник рассказов как тематическая мозаика и жанровый гибрид («Сараевский Мальборо» М. Ерговича и «Дьявол в Сараеве» Н. Величковича) // Гибридные формы в славянских культурах, Москва, Институт славяноведения РАН, сс. 193-200.

Ткачук, Т., Шарый, А. (2004). Боснийский выпуск. Мильенко Ергович. “Скорость темноты”, у: Радио Свобода, http://archive.svoboda.org/programs/EX/2002/EX.061602.asp. (pristupljeno dana 10. ožujka 2019. godine).

Ходел, Р. (2009). Текстуална кохеренција “сказа” на примјеру “Јалове јесени” Драгослава Михаиловића, y: http://www.rastko.rs/rastko/delo/13172 (pristupljeno dana 10. ožujka 2019. godine).

Primljeno 15. februara 2019. godine, nakon revizije, prihvaćeno za publikovanje 28. marta 2019. Elektronska verzija objavljena 10. aprila 2019.

Polina Korolkova je završila slavističke studije na Moskovskom državnom sveučilištu Lomonosov gdje je 2011. godine doktorirala. Bavi se suvremenim književnostima Hrvatske, Srbije, Bosne i Hercegovine i Crne Gore, kao i češkom književnošću. Predaje stručne predmete na Katedri za slavistiku i srednjoeuropska istraživanja Fakulteta za povijest i filologiju Ruskoga državnog humanističkog sveučilišta (RGGU). 


\section{ТЕМАТИЧЕСКАЯ МОЗАИЧНОСТЬ И ЖАНРОВЫЕ МОДИФИКАЦИИ В «САРАЕВСКОМ МАЛЬБОРО» МИЛЕНКО ЕРГОВИЧА}

В сборнике рассказов Миленко Ерговича «Сараевские Мальборо» мы находим разные по своему характеру и стилю произведения, которые сами по себе могли бы относиться к разным жанрам. Это и очерки, и эссе, и монологи, и диалоги, даже сказки. Подобная пестрота, необходимая автору для достижения определенных целей (воссоздать живую картину города, показать людей из разных слоев общества, разных национальностей и возрастов, их жизнь в блокадном Сараево), делает текст по-настоящему богатым и интересным.

Хотя в книге описывается военное время, мы не найдем здесь картин бомбёжек, человеческих страданий, философских размышлений о смысле войны и насилия, жизни и смерти и т.д. В статье будут предложены ответы на вопросы: как и почему автор нарушает читательские ожидания в области тем и жанров, почему обращается к принципу жанровой гибридизации и как она связана с пестротой тематики, почему сборник «Сараевские Мальборо» можно читать исключительно как единый текст, все части которого неразрывно связаны.

Ключевые слова: хорватская литература, Миленко Ергович, «Сараевские Мальборо», очерк, эссе.

\footnotetext{
${ }^{1}$ Vidjeti: (Королькова, 2014).

${ }^{2}$ Detaljnije o tome kako Miljenko Jergović doživljava taj žanr i njegovu ulogu u suvremenoj književnosti vidjeti: (Ткачук, Шарый, 2004).

${ }^{3}$ Vidjeti: (Ткачук, Шарый, 2004).

${ }^{4}$ Vidjeti: "Što se dalje događalo ne znam... no to više i nije važno... No ono što seže i izvan granica ove priče je ta potreba da se konstruira fabula, da se načini okvir koji bi opravdao sam život i koji bi mu naposljetku dao nekakav smisao“ (Jergović, 2004, 98) (Fotografija).

${ }^{5}$ Kazivanje, ili skaz je ,narativna forma, koja se razvila u ruskom realizmu sa Gogoljevim Šinjelom (1841), u djelu Nikolaja Ljeskova doživjela svoj prvi vrhunac...“" (Ходел). Teorija skaza ruskog filologa Borisa Ejhenbauma (razrađena u znanstvenim dijelovima Jurija Tynjanova) naglašava da je to ,jedan drugačiji način pripovjedačkog govora, a time i pripovjedača... To je usmeni govor... naspram književnog stila, narodni govor... naspram govora obrazovanih slojeva ili tuđi govor... naspram vlastitog (auktorijalnog) govora..." (Ходел).
} 